\title{
BINOMIAL TERMINOLOGICAL COLLOCATIONS WITH AN ADJECTIVE-CONTAINING METAPHORICAL COMPONENT
}

\section{Teleky Mariia ${ }^{1}$ Synytsia Valentyna ${ }^{2}$}

DOI: https://doi.org/10.30525/978-9934-571-89-3_6

Modern terminology is characterized by the development of three main paradigmatic areas - systemic-structural/traditional, functional and cognitive. Cognitive approach exploring regularities in the terminological organization of various fields of knowledge is of special importance.

The study of the processes of term formation due to metaphorization, mechanisms of secondary nomination, definition of lexical-semantic structural types and wordbuilding means in scientific medical terminological systems remains rather topical.

Formation of the cognitive direction in terminological science was contributed by the works of NN. Volodina, 1998; V.M. Leichik, 2007; A.V. Bekishova, 2007; A.V. Varnavska 2009; L. Yu. Buyanova, 2012; A.A. Selivanova, 2013).

Investigation of metaphorical names in medical terminology as an important method to create secondary nomination was conducted by S. Dudetska, 2007; N. The Emperor 2010; Y. Brazhuk, 2012; N. Morozova 2013; L. Shutak, G. Navchuk, 2016; M. Teleky, A. Myronyk, 2018. However, terminological collocations with metaphorical component functioning in the field of infectology remain insufficiently studied.

The objective of the article is to characterize the cognitive mechanisms of metaphorization on the material of the Ukrainian language, reflected in collocations

\footnotetext{
${ }^{1}$ Higher State Educational Establishment of Ukraine

"Bukovinian State Medical University", Ukraine

${ }^{2}$ Higher State Educational Establishment of Ukraine

"Bukovinian State Medical University", Ukraine 
functioning in medical terminology concerning infectious diseases. To achieve this goal it is necessary to: 1) identify and describe some of the binomial terminological collocation with an adjective-containing metaphorical component; 2) find out the initial sources and recipient zones; 3) reveal the internal relations between the primary meaning and the scientific concept formed on its basis.

The materials of the study were selected from: Ukrainian-Russian-Latin-English Medical Encyclopaedic Dictionary A-Z: (edited by Petrux L.I., Golovko I.M.) [6], Symptoms and syndromes in infectious diseases (edited by Titov M.B., Titov V.M.) [5].

The cognitive mechanisms of metaphorization are based on the theory of conceptual metaphors by J. Lakoff and M. Johnson, according to which metaphorization occurs as a process of interaction between knowledge structures of two conceptual spheres [3, p. 133] - spheres of sources (the experience learned by a person in the process of cognition of a reality fragment) and a target sphere or a recipient zone (transfer from the sphere of the source of signs of a certain reality object to name another one due to similarity).

The study of metaphor makes understanding it as a phenomenon of language, thinking and reality. In medical terminology that has been formed over the centuries, terminological systems, due to separate terminal units-collocations, retain metaphorical concepts as figurative and mental formations that elucidate associative relations of reality cognoscible by man at a certain stage of development of society and recorded in the language as a result of human verbal activity.

Binomial substantive collocations are widely represented in the terminology of infectology. This class of lexical units - with the noun in the role of the main word, combined with an adjective, reproduces a stable structure of a special concept. The metaphorical component, depending on the main word and phrase, explains the internal relationa between objects and phenomena, reveals and specifies the notion coming to the mind of an individual while mentioning another notion on the basis of certain common features known from the previous experience. The process of transferring similar properties from the source sphere to the recipient zone occurs.

To create metaphorical nominations for infectious diseases more than twelve source spheres have been described [4]. The following spheres are singled out in our study:

- anthropomorphic one, formed by the similarity of physiological and pathophysiological characteristics of a person or the results of various types of human activities, such as:

- tetanus - an acute infectious disease characterized by lesions of the nervous system, paroxysms of tonic and clonic convulsions. In case of acrobatic tetanus, as a result of tonic muscle contraction, the patient's body assumes a strange position) [1, p. 1180], that is, resembles an acrobat, making it difficult to move the body;

- lethargic encephalitis (syn. sleeping sickness, of Economo encephalitis) inflammation of the brain of an infectious origin; metaphoric nomination is associated with similarity to sleep - physiological condition of rest, when a person completely ceases the work of consciousness and decreases the response to external 
stimuli. The metaphoric lethargic component is an adjective, noun-motivated lethargy

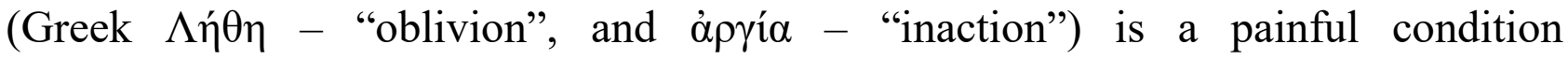
characterized by slowness, lethargy, fatigue [2]. Ukrainian Dictionary describes lethargy as: 1) a painful condition, like a dream, with almost unheard breathing and pulse; 2) figurative meaning - complete imobility, inactivity (Ukrainian dictionary in 11 volumes: Volume 4, 1973. P. 479.). Lethargic sleep in general sense is a fictitious state and is described only in fiction.

- zoomorphic: similarity of signs with the external features of animals:

- Leopard skin - numerous small hemorrhages on the skin, grouped in the form of spots observed with thrombocytopenic purpura; similar to the skin of the beast with spots that form ring shapes with a light middle;

- the lion face (syn. Leontiasis < Greek. Leon, leontos a lion) - a sharp hypertrophy of the soft tissues of the face, often with their deformation, giving the face a lion appearance; observed in case of leprosy, certain leukemia cases;

- components using a color palette:

- red vaccine (syn. False cowpox, paravaccine, milkmaids nodules) - an infectious disease caused by a virus from the paravaccine group transmitted to humans by contact from cattle, sheep and goats; characterized by the formation of red papules on the skin of the hands;

- smallpox or black pox - highly contagious viral infection. In typical cases, smallpox is characterized by general intoxication, fever, peculiar rashes on the skin and mucous membranes, successively passing through the stages of stains, vesicle, pustules, crusts and scar. From the VI century has been recorded under the Latin name variola, according to which people on different continents died every year. In case of hemorrhagic form of the disease (black pox), the cavity of the vesicles and pustules contain blood admixtures changing their color to black. Metaphorical component is reflected in many languages and reflects the world outlook through the creative rethinking of the national picture of the world. For example, in India, the Goddess of smallpox - Mariatale is honoured. A legend tells that a young woman, getting angry with her father, threw a golden necklace into his face in anger. And where the beads touched the skin pustules appeared immediately [7].

Binomial terminological collocations with a metaphorical component in infectology retain accumulated knowledge concerning infections, infectious processes, diseases and pathologies of human and animal organisms. The metaphorical component demonstrates internal relations between the fragment of reality and the object transferred due to the comparison of similar properties and reflects the metaphorical thinking peculiar for certain linguistic culture.

Further studies assume description of the type of collocations with the eponymous component functioning in the terminological system of infectology.

\section{References:}

1. Bolshoy entsiklopedicheskiy slovar meditsinskih terminov Bol'shoy entsiklopedicheskiy slovar' meditsinskikh terminov / pod red. Prof. E.G. Ulumbekova. Moskva: G.EOTAR-Media. 2012. $2263 \mathrm{p}$. 
2. Letarhiia [Lethargy]. URL: https://www.rightdiagnosis.com/sym/lethargy.htm (Last accessed: 21.02.2019).

3. Nazarchuk R. (2015) Tlumachennia mekhanizmiv metaforyzatsii v suchasnomu movoznavstvi. [Interpretation of the mechanisms of metaphorization in modern linguistics]. Humanity, computers and communication (hcc'2015). Lviv, Ukraine, pp. 133-135.

4. Teleky M., Myronyk O. Metaforychni nominatsii yak reprezentatsiia medychnykh znan. [Metaphoric nomination for the representation of medical knowledge]. Aktualni pytannia suspilnykh nauk ta istorii medytsyny. - Sp. ukr.-rum. zh. Seriia (Filolohichni nauky) Current issues of social stadies and history of medicine. Joint Ukrainian-Romanien scientific journal Chernivci - Suchava: BDMU. 2018, no. 1 (17), pp. 34-39.

5. Tytov M.B., Tytov V.M. (1993). Symptomy i syndromy pry infektsiynykh khvorobakh [Symptoms and syndromes in infectious diseases], Lvivskyi derzhavnyi medychnyi instytut [Lviv state med. univ.].

6. Petrukh L.I., Holovko I.M. (2015).Ukrainsko-latynsko-anhliiskyi medychnyi entsyklopedychnyi slovnyk: A-Ya [Ukrainian-Latin-English medical encyclopaedic dictionary]. VSV "Medytsyna" ["Medicine"].

7. URL: https://ru.wikipedia.org/wiki/Naturalnaya_ospa (Last accessed: 21.02.2019). 